\title{
ЦИКЛОООБРАЗУЮЩИЕ ФУНКЦИИ ЛЕКСИЧЕСКИХ ПАРАДИГМ ЛИРИЧЕСКОГО ЦИКЛА И.А. БУНИНА «ПЕСНИ О ВЕСНЕ»
}

\author{
І.А. ПРОСКУРІН. ЦИКЛОТВОРЧІ ФУНКЦІЇ ЛЕКСИЧНИХ ПАРАДИГМ ЛІРИЧНОГО \\ ЦИКЛУ І. О. БУНІНА «ПІСНІ ПРО ВЕСНУ». \\ У статті запропоновано парадигматичний аналіз лексики ліричного ииклу І. А. Буніна
} «Пісні про весну», щзо має на меті дослідження - визначити ииклотворчі функиії лексичних парадигм. Усі твори циклу поєднують у своєму складі риси проєктивності та концептуальності. Конщептуальність та проєктивність репрезентовані двома домінантними парадигмами, щяо повторюються в усіх віршах ииклу «Пісні про весну» - парадигмами ПРИРОДА (проективний аспект) та ЛІРИЧНИЙ ГЕРОЙ (кониептуальний аспект). Парадигма ПРИРОДА та парадигма ЛІРИЧНИЙ ГЕРОЙ взаємопов'язані. Зміни складу парадигми ПРИРОДА призводять до змін складу парадигми ЛІРИЧНИЙ ГЕРОЙ. У першому вірші циклу «Пісні про весну» природа знаходиться у стані очікування весни як пори оновлення. Ці відчуття поєднано з відчуттями ліричного героя. Весняне тепло, щзо огортає природу у наступному вірші ииклу «Пісні про весну», віддзеркалено у відчуттях ліричного героя як стан, споріднений до сп'яніння. СПОКІЙ та РУХ ПРИРОДИ у третьому вірші ииклу «Пісні про весну» ліричний герой відчуває крізь сінестетичні зорові та звукові образи. «Вранішні співи солов їні» у вірші «То розростаючись, то невиразно...»голос Весни, який ліричний герой відчуває як невидиму гармонію. У заключному вірші ииклу «Пісні про весну» парадигма ПРИРОДА поєднується з парадигмою БАТЬКІВЩИНА, надаючи відчуттям ліричного героя конкретні риси. Це є пов'язаним з тим, що конщепт БАТЬКІВЩИНА сенсотвірний для всієї творчості І.О. Буніна. Батьківщина у розумінні поета - не тільки рідний край та його конкретна частина, в якій народилася людина, де відбулося ї̈ становлення як особистості, а органічно належна людині риса, що детермінує ї̈ світогляд.

Ключові слова: функиіональний підхід у дослідженні мовних явищ, парадигматичний аналіз лексики, мовознавче дослідження поетичного тексту.

\section{И.А. ПРОСКУРИН. ЦИКЛООБРАЗУЮЩИЕ ФУНКЦИИ ЛЕКСИЧЕСКИХ ПАРАДИГМ} ЛИРИЧЕСКОГО ЦИКЛА И.А. БУНИНА «ПЕСНИ О ВЕСНЕ».

В статье предлагается парадигматический анализ лексики лирического иикла И.А. Бунина «Песни о весне», преследуюший цель определить ииклообразующие функции лексических парадигм. Все произведения иикла объединяют черть проективности и концептуальности. Конщептуальность и проективность репрезентированы двумя доминантными парадигмами, повторяющилися во всех стихотворениях иикла «Песни о весне», - парадигмы ПРИРОДА (проективный аспект) и ЛИРИЧЕСКИЙ ГЕРОЙ - конщептуальный аспект. ЭТИ ПАРАДИГМЫ взаимосвязаны. Изменения состава парадигмы ПРИРОДА приводят к изменению состава парадигмы ЛИРИЧЕСКИЙ ГЕРОЙ. В первом стихотворении ичикла «Песни о весне» природа находится в состоянии ожидания весны как поры обновления. Эти ощущения объединены с омущениями лирического героя. Весеннее тепло, распространяющееся в природе, в следуюшем стихотворении иикла «Песни о весне» отражено в ошущениях лирического героя как состояние, родственное опьянению. ПОКОЙ и ДВИЖЕНИЕ ПРИРОДЫ в третьем стихотворении иикла "Песни о весне» лирический герой ощущает через синестетические зрительные и слуховые образы. «Напевы ранних соловьёв» в стихотворении «То разрастаясь, то невнятно...» - голос Весны, ошушщаемый лирическим героем как невидимая гармония. В заключительном стихотворении цикла «Песни о весне» парадигма ПРИРОДА объединяется с парадигмой РОДИНА, придавая ощущениям лирического героя конкретность. Это связано с тем, что концепт РОДИНА является смыслообразующим для всего творчества И.А. Бунина. Родина в понимании поэта - не только родной край и его конкретная область, в которой родился человек, где произошло его становление как личности, а органически присущая человеку черта, определяющая его мировоззрение. Ключевые слова: функциональный подход к исследованию языковых явлений, парадигматический анализ лексики, лингвистическое исследование поэтического текста.

() И.А. Проскурин, 2019

https://doi.org/10.34142/2312-1572.2019.02.68.06 
I. PROSKURIN. A CYCLIC-FORMER FUNCTION OF LEXICAL PARADIGMS FOR BUNIN'S LYRIC CYCLE «SONGS ABOUT SPRING».

The article gives paradigmatic analysis of lexicon for Bunin's lyric cycle «Songs about spring». The article's aim is determination of cyclic-former functions for lexical paradigms in Bunin's lyric cycle «Songs about spring». All poems of cycle tied in its content features of projectivity and features of the conceptuality. Conceptuality and projectivity represented by dominant paradigms repeated in all cycle's poems. There are paradigms NATURE (projective aspect) and LYRIC HERO - conceptual aspect. Both paradigms are tied. Changes for paradigm's NATURE content cause changes for paradigm's LYRIC HERO content. In the first poem of the cycle nature wait spring as period of renovation. In the next poem of the cycle nature covered by the spring's heat. This phenomenon represented in lyric hero's perception as inebriation condition. PEACE and MOVEMENT OF THE NATURE in third poem of the cycle felt by lyric hero with synesthetic visual and auditory images. "Melodies of early nightingales» in poem «Nightingales» is a voice of Spring felt by lyric hero as unseen harmony. In final poem of the cycle paradigm NATURE tied with paradigm MOTHERLAND. This phenomenon cause concrete lyric hero's perception. Concept of Motherland is semantic for Bunin's legacy. It is determine worldview's feature. Motherland in Bunin's meaning is a concrete region for identity creation.

Key words: functional way to research of language phenomena, paradigmatic analysis of lexicon, linguistic research of poetical text.

Стихотворения о временах года занимают особое место в поэзии: часто та или иная пора года выступает основанием для рефлексии и медитации.

Примером может служить лирика И.А. Бунина.

«Песни о весне» И.А. Бунина были напечатаны в седьмой книжке «Вестника Европы» за 1893 год. Это цикл из пяти стихотворений пейзажного типа, написанных в традиционной рефлексивно-медитативной манере. Цель данной статьи - выявить и исследовать при помощи парадигматического анализа черты лексики, объединяющие стихотворения в единый цикл «Песни о весне». Выделяемые лексические парадигмы рассматриваются как генерируемые системой «предметных» образов, которые возникают у реципиента в процессе восприятия текста и формируют содержание произведения (см. об этом подробнее в [5, с. 13-19]).

Открывается цикл стихотворением «Светлеют с каждым днём и молодеют сосны»:

Светлеют с каждым днём и молодеют сосныл:

Чернеет лес; теплей синеет даль;

Сдаётся, наконеи, сырым ветрам февраль,

И потемнел в лощинах снег наносный.

На гумнах и в саду по зимнему покой

Царит в затишье дедовских строений;

Но что-то тянет в зал, холодный и пустой,

Где пахнет сыростью весенней...

Сквозь стёкла зимние заклеенных дверей

Гляжу я на балкон, где снег ещё навален,

И гольй, тёмный сад теперь мне не печален,

И в чёрных сучьях лип я жду уже грачей.

Жду, как любви, как отдыха и воли,

Туманов мартовских, чернеюших бугров,

И света, и тепла от бельх облаков,

И первых жаворонков в поле!

В стихотворении совмещаются черты текстов проективного и концептуального типов (под проективностью подразумевается ориентация текста преимущественно на конкретночувственное восприятие, под концептуальностью - преимущественно на понятийное [3]). Проективный и концептуальный аспекты содержания формируют две основные, доминантные парадигмы, повторяющиеся во всех стихотворениях цикла: ПРИРОДА (проективный аспект) сосныл; лес; даль; снег; сырость; грачи; туманы; облака; жаворонки и ЛИРИЧЕСКИЙ ГЕРОЙ и его ощущения (концептуальный аспект) - гляжу я; мне не печален; я жду. Обе парадигмы включены в гиперпарадигму ПРЕДЧУВСТВИЕ ОБНОВЛЕНИЯ и взаимосвязаны: изменения состава парадигмы ПРИРОДА приводят к изменениям в составе парадигмы ЛИРИЧЕСКИЙ ГЕРОЙ. 
ПарадигмЫ ПРИРОДА и ЛИРИЧЕСКИЙ ГЕРОЙ связаны с парадигмой ЗИМА ПРОХОДЯЩАЯ ПОРА ГОДА (потемнел в лощинах снег наносный; балкон, где снег ешё навален), противопоставленной парадигме ВЕСНА - ОБНОВЛЕНИЕ, НОВАЯ ПОРА ГОДА (грачи; мартовские туманы; свет и тепло белых облаков).

Изменения в природе связаны с изменениями в душе лирического героя (гольй; тёмный сад теперь мне не печален).

За счёт противопоставления временных пластов настоящего и будущего в природе и в душе лирического героя формируется основная антитеза, на которой построено стихотворение: покой, безжизненность, печаль, холод ЗИМЫ противопоставлены свету, теплу и воле ожидаемой ВЕСНЫ, гиперпарадигмы стихотворения, объединяющей остальные парадигмы.

Парадигма ЛИРИЧЕСКИЙ ГЕРОЙ в стихотворении «Светлеют с каждым днём и молодеют сосны...» выражена имплицитно, то есть неявным образом: герой не присутствует в тексте как активный участник происходящих событий, а находится «снаружи» стихотворения, наблюдая за происходящим и выступая своеобразной импликатемой в структуре стихотворения, проявляющейся как своего рода угол зрения.

Следующее стихотворение цикла «Бушует полая вода...»:

Бушует полая вода

В лощинах глухо и протяжно;

Грачей пролётные стада

Кричат и весело, и важно,

За лугом чёрные бугры

Дымятся в воздухе нагретом,

И всюду мягким бельм светом

Стоят тяжёлье пары.

А в полдень лужи у крыльца

Так разливаются и блешут,

Что в нашей «детской» без конияа

По стенкам «зайчики» трепещут...

Меж бельх рыхлых облаков

Невинно небо голубеет,

И солние ласковее греет

В затишье гумен и дворов...

Совсем весна! Как всё ей радо!

Как в забытье каком стоишь

И сльшишь свежсии запах сада

И тёплый запах тальх крыши..

Всё на селе живёт, сверкает,

Крик петухов звучит весной,

А ветер, лёгкий и сырой,

Глаза тихонько закрывает.

Текст стихотворения носит преимущественно проективный характер и ориентирован в основном на описание конкретных признаков весны и ощущений, вызываемых весной в душе ЛИРИЧЕСКОГО ГЕРОЯ. Гиперпарадигма ВЕСНА (совсем весна! Как всё ей радо!) объединяет парадигмы ПРИРОДА (бушует полая вода в лошинах глухо и протяжно; грачей пролётные стада кричат и весело, и важно; за лугом чёрные бугры дымятся в воздухе нагретом, и всюду мягким бельми светом стоят тяжёлье пары; лужи разливаются и блещут; меж белых рыхлых облаков невинно небо голубеет, и солнще ласковее греет в затишье гумен и дворов; ветер, лёгкий и сырой) и ЛИРИЧЕСКИЙ ГЕРОЙ (как в забытье каком стоишь и слышишь свежий запах сада и тёплый запах тальхх крыш).

Это стихотворение связано с предыдущим однотипностью (одноимённостью) парадигм, однако состав их различен: если в первом стихотворении в парадигме противопоставлены подпарадигмы, включающие обозначения атрибутов зимы и только начинающейся весны, то в данном стихотворении в парадигме ПРИРОДА на смену обозначениям атрибутов зимы приходят слова, обозначающие следующий этап наступления весны (бушующая, глухо $u$ протяжно, в лощинах вода; дымящиеся в нагретом воздухе бугры; стоящие всюду тяжёлье nары; трепещущие по стенкам «детской» «зайчики»; голубеющее невинно небо; ласково греющее солнще; запахи весны: запах сада и запах тальх крыш). Противопоставление весны 
зиме исчезает. Соответственно меняется состояние лирического героя. Парадигма ОЖИДАНИЕ сменяется парадигмой ЧУВСТВО НАЧАЛА ВЕСНЫ (грачей пролётные стада кричат и весело и важно; а в полдень лужи у крыльца так разливаются и блещут; как в забытьи каком стоишь; всё на селе живёт, сверкает; а ветер, лёгкий и сырой, глаза тихонько закрывает). Стремясь к максимально конкретному описанию, Бунин прямо называет время суток (полдень - самое тёплое время дня). В другое время суток ощущение начала весны будут иными. Видимо, такая конкретность описания впечатлений от восприятия определённого (данного) момента позволила исследователям говорить об импрессионизме Бунина [2].

Следующее стихотворение цикла «Догорел апрельский поздний вечер...»:

Догорел апрельский поздний вечер,

По лугам холодный сумрак лёг;

Спят грачи; далёкий шум потока

В темноте таинственно заглох.

Но свежее пахнет зеленями

Молодой озябший чернозём,

И струится чище над полями

Звёздный свет в молчании ночном.

По лошинам, звёзды отражая,

Ямы светят тихою водой;

Журавли, друг друга окликая,

Осторожной тянутся гурьбой...

А весна стоит - забылась в роще

И, как бы дыханье затая,

Чутко сльишт каждый лёгкий шорох,

Зорко смотрит в тёмные поля...

Стихотворение, как и предыдущее, относится к текстам преимущественно проективного типа. Парадигма ЛИРИЧЕСКИЙ ГЕРОЙ здесь также выражена имплицитно: доминантная парадигма ПРИРОДА в последней строфе объединяется с парадигмой ВЕСНА. Лирический герой (Я) - это точка зрения человека, чувствующего запахи, звуки (образы природы дифференцируются по модальности), картины вечера в апреле. Парадигма ВЕСНА персонифицирована (стоит - забылась в роще; дыханье затая; слышит каждый лёгкий шорох; смотрит в тёмные поля). В парадигме ПРИРОДА имеет место метафоризация (догорел апрельский поздний вечер) и персонификация (по полям холодный сумрак лёг; журавли, друг друга окликая, осторожной тянутся гурьбой), вызывающие в сознании читателя синестетические зрительные и звуковые образы. В целом, стихотворение построено на противопоставлениях: вторая строфа противопоставлена первой, четвёртая строфа противопоставлена третьей. Противопоставление происходит по линии ДВИЖЕНИЕ и ПОКОЙ. Понятие ПОКОЙ в первой строфе (догорел апрельский поздний вечер; по лугам холодный сумрак лёг; спят грачи; далёкий шум потока в темноте таинственно заглох) на лексическом уровне определяется глаголами: догорел; лёг; сnят; заглох. Движение во второй строфе осуществляется плавно, что достигается благодаря вовлечению в общую лексическую ткань стихотворения глагольной лексемы струится («распространяться, направляться откудалибо, куда-либо несильным потоком» [3, с. 1081-1082]). Таким образом, следующая фаза весны связывается с усилением ощущения плавного движения и общего накала эмоциональности описания, выраженного метафорами и персонификацией.

Следующее стихотворение цикла «То разрастаясь, то невнятно...»:

То разрастаясь, то невнятно

Гром за усадьбой грохотал;

Как тусклые слепые пятна,

На стёкла сумрак набегал;

Всё ниже тучи напльввали,

Всё ошутительней, свежей

Порывы ветра обвевали

Дождём и запахом полей;

Кмежам, шумя, хлеба клонились...

А из лошин и из садов -

Отвсюду с ветром доносились 
Напевы ранних соловьёв...

Но вот отчаянно упрямо

Порыв последний налетел -

Сухой бурьян зашелестел,

Захлопнулась со звоном рама,

Пахнуло в комнаты дождём...

Раскат проснувшегося грома

Ударил вдруг над крышей дома

И прокатился... Всё кругом

Затихло сразу, непонятно;

Сад потемневший присмирел -

И широко и благодатно

Весенний ливень зашумел...

На межи низко наклонились

Хлеба в полях... А из садов

Всё так же звучно доносились

Напевы ранних соловьёв...

Когда же, медленно слабея,

Дождь отшумел и замер гром,

Ночь переполнила аллеи

Благоуханьем и теплом.

Пар неподвижный и пахучий

Стоял в хлебах. Спала земля.

Заря чуть теплилась под тучей

Полоской алого огня.

А из лощин, где распускались

Во тьме иветьи, и из садов

Лились и в чащах отдавались

Напевы ранних соловьёв!..

Доминантной парадигмой в этом стихотворении выступает ПРИРОДА (тучи напльвали; порывы ветра обвевали дождём и запахом полей; сухой бурьян зашелестел; сад присмирел; ливень зашумел; дождь отшумел; заря чуть теплилась), зафиксированная в различных состояниях, объединяемых при помощи рефрена напевы ранних соловьёв, выступающего, по мнению А. Орлова, «характерным композиционным приёмом поэтики Бунина» [2, с. 74-75]. Проанализируем выделенные элементы природной парадигмы. Наличие глаголов движения (напльвали; обвевали; зашелестел; зашумел) формирует эффект динамики развития лирического сюжета стихотворения. Элементы природной парадигмы персонифицируется, тучи, ветер, бурьян, сад, ливень, дождь, заря предстают как живые объекты. Hапевы ранних соловьёв - голос Becны, слышимый лирическим героем, её невидимая и непостижимая гармония. Гром, дождь, соловь $и$ - признаки мая - следующего этапа весны. От стихотворения к стихотворению проективность текста возрастает: всё меньше прямой оценки, непосредственного выражения эмоций, за исключением вывода (заключительных строк завершающего цикл стихотворения).

Завершает цикл стихотворение «Ещё от дома на дворе»:

Ещё от дома на дворе

Синеют утренние тени

И под навесами строений

Трава в холодном серебре;

Но уж сияет яркий зной,

Давно топор стучит в сарае,

И голубей весёльх стая

Блестит на солнце белизной.

С зари кукушка за рекою

Кукует звучно вдалеке,

И в молодом березняке

Так пахнет зеленью лесною;

Трепещет радостно, смеётся 
Под солнием чистая река,

И голоса, и стук валька -

Всё в роще гулко отдаётся...

$A$ за деревнею, где межи

В хлеба привольные бегут,

Где хуторки белеют реже -

Ржи наливаются, иветут;

Струится зной, синеют рощи,

Даль безмятежна и ясна...

Что в свете радостней и проще

И где прекраснее весна?

В стихотворении «Ещё от дома на дворе...» можно выделить парадигму ПРИРОДА (трава; зной; голуби; солнце; кукушка; река; березняк; зелень) и парадигму РОДИНА, выступающую импликатемой настоящего стихотворения (что в свете радостней и проще и где прекраснее весна?). Гиперпарадигма ВЕСНА объединяет парадигмы ПРИРОДА и РОДИНА. Внутри природной парадигмы может быть выделена подпарадигма ПТИЦЫ (голуби; кукушка), персонифицирующие голос Весны, которому внимает лирический герой. Стихотворение «Ещё от дома на дворе...» можно считать кульминационным, поскольку природная парадигма, проходящая через весь цикл, включается в оценочную парадигму РОДИНА. Эта парадигма присутствует во всех стихотворениях цикла. Эмоциональный мир лирического героя, порождённый впечатлениями от весны, совпадает во всех стихотворениях цикла, и это позволяет распространить на них вывод поэта, сделанный в последнем стихотворении.

Бунинский цикл «Песни о весне» представляет собой ряд поэтических текстов, основным циклообразующим признаком которых является наличие парадигмы ВЕСНА, выполняющей функцию гиперпарадигмы. Структура этой гиперпарадигмы в каждом стихотворении цикла различна.

В цикле речь идёт о следующих друг за другом периодах весны от февраля по июнь. Каждый из них характеризуется своими неповторимыми особенностями. К примеру, «Светлеют с каждым днём и молодеют сосны...» - переход от покоя к движению. С каждой ипостасью Весны связано определённое эмоциональное состояние лирического героя, воспринимающего Весеннюю симфонию, в которой «Светлеют с каждым днём и молодеют сосны...»- аллегро; «Бушует полая вода...» - модерато; «Догорел апрельский поздний вечер...» - престо; «То разрастаясь, то невнятно...»- лярго; «Ещё от дома на дворе...» - аллегро. Если продолжить аналогию между бунинским лирическим циклом и музыкальным произведением, то каждому стихотворению можно приписать признаки определённого лада, который выражается в виде простейшей каденции T-S-D-T (созвучие тоники (устойчивый аккорд лада) - созвучие субдоминанты (центробежный элемент гармонии) - созвучие доминанты (центростремительный элемент гармонии) - созвучие тоники). В стихотворении «Светлеют с каждым днём и молодеют сосны...» созвучие тоники - природная парадигма (cocнbl; лес; даль; снег; сырость; грачи; туманы; облака; жаворонки); созвучие субдоминанты - УХОД ЗИМЫ (сдаётся, наконеи, сырым ветрам февраль и потемнел в лощинах снег наносный; на гумнах и в саду по зимнему покой; снег ещё навален; гольй, тёмный сад); созвучие доминанты - ПРИХОД ВЕСНЫ (теплей синеет даль; пахнет сыростью весенней; мартовские туманы; чернеющие бугры; жаворонки). В стихотворении «Бушует полая вода...» созвучие тоники - природная парадигма (бушует полая вода в лощинах глухо и протяжно; грачей пролётные стада кричат и весело, и важно; за лугом чёрные бугры дымятся в воздухе нагретом, и всюду мягким бельм светом стоят тяжёлье пары; лужи разливаются и блешут; меж белых рыхлых облаков невинно небо голубеет, и солнце ласковее греет в затишье гумен и дворов; ветер, лёгкий и сырой); созвучие субдоминанты - парадигма НАЧАЛО ВЕСНЫ (бушуюшая, глухо $и$ протяжно, в лощинах вода; дымящиеся в нагретом воздухе бугры; стоящие всюду тяжёлые пары; трепещущие по стенкам «детской» «зайчики»; голубеющее невинно небо; ласково греющее солнще; запахи весны: запах сада и запах талых крыш); созвучие доминанты ОЩУЩЕНИЯ ЛИРИЧЕСКОГО ГЕРОЯ (как в забытьи каком стошшь). В стихотворении «Догорел апрельский поздний вечер...» созвучие тоники - природная парадигма; созвучие субдоминанты - парадигма ДВИЖЕНИЕ; созвучие доминанты - парадигма ПОКОЙ. В стихотворении «То разрастаясь, то невнятно...» созвучие тоники - природная парадигма (тучи напльвали; порывы ветра обвевали дождём и запахом полей; сухой бурьян зашелестел; сад 
присмирел; ливень); созвучие субдоминанты - восприятие майской природы лирическим героем; созвучие доминанты - напевы ранних соловьёв. В стихотворении «Ещё от дома на дворе...» лад выглядит как половинный каданс T-D: созвучие тоники - природная парадигма (трава; зной; голуби; солнще; кукушка; река; березняк; зелень); созвучие доминанты - оценочная парадигма РОДИНА (что в свете радостней и проще и где прекраснее весна?).

Таким образом, в цикле состав и функции однотипних парадигм изменяются. Лирический герой как персонаж в стихотворениях отсутствует, но он присутствует как наблюдатель изменений весенней природы, в сознании которого эти изменения приобретают эмоциональную оценку, выраженную в основном имплицитно, за счёт ассоциативных оценочных парадигм. Предельная локально-временная определённость, «привязанность» парадигм (т. е. изменения природы и эмоционального состояния здесь и сейчас) позволяют говорить об импрессионизме Бунина. Изменение состава и функций частных парадигм связано с изменением соотношения проективности и концептуальности цикла в целом. Как уже отмечалось, изменения состава парадигмы ПРИРОДА приводят к изменениям состава парадигмы ЛИРИЧЕСКИЙ ГЕРОЙ. В стихотворении «Светлеют с каждым днём и молодеют сосны...» природа ожидает весну как вестницу обновления. Эти ощущения созвучны ощущениям лирического героя. Весеннее тепло, окутывающее природу в стихотворении «Бушует полая вода...», ощущается лирическим героем как состояние, родственное опьянению (как в забытьи каком стоишь!). ПОКОЙ и ДВИЖЕНИЕ ПРИРОДЫ в стихотворении «Догорел апрельский поздний вечер...» ощущается лирическим героем через синестетические зрительные и звуковые образы. «Напевы ранних соловьёв» из стихотворения «То разрастаясь, то невнятно...» - голос Весны, который лирический герой ощущает как непостижимую и невидимую гармонию. Наконец, в стихотворении «Ещё от дома на дворе...» парадигма ПРИРОДА объединяется с парадигмой РОДИНА и конкретизирует ощущения лирического героя. Это связано с тем, что концепт РОДИНА - смыслообразующий для всего творчества И.А. Бунина, писателя с обострённым чувством Родины. Родина - не просто место на карте, а органически присущее человеку качество, определяющее его мировосприятие, и это придаёт творчеству Бунина глубокий философский смысл.

\section{ЛИТЕРАТУРА}

1. Бунин И.А. Песни о весне. Вестник Европы. Спб, 1893 (№7). С. 362-365.

2. Орлов А. Специфика художественного образа в ранней лирике И. Бунина. Філологічні науки. Збірник наукових праць. Випуск 14. Полтава, 2013. С. 73-79.

3. Правдин М.Н. Анализ содержательной структуры текста: Сборник научных трудов МГПИИЯ имени М. Тореза, вып. 103. М., 1976. С. 91-102.

4. Словарь современного русского литературного языка. Том 14. М., Л.: Издательство AH CCCP, $1963.700 \mathrm{c}$.

5. Степанченко И.И., Мирошниченко М.В., Нестеренко К.В., Пехарева М.В., Просяник О.П. Парадигматический анализ лексики поэтического произведения. К.: Українське видавництво, 2014. 216 с.

6. Степанченко И.И. Основные аспекты изучения языка в функциональной лингвистической парадигме. Русская філологія: Вестник ХНПУ им. Г.С. Сковородыл. Харьков, 2016. № 4. C. $8-14$.

(Статья поступила в редакцию 2 апреля 2019 г.) 